\title{
ANGLOJĘZYCZNE PIŚMIENNICTWO NAUKOWE W DZIEDZINIE TURYZMU
}

\section{LA LITTÉRATURE SCIENTIFIQUE EN LANGUE ANGLAISE DANS LE DOMAINE DU TOURISME}

\section{ENGLISH SCIENTIFIC LITERATURE ON TOURISM}

\begin{abstract}
W artykule dokonano przeglądu czasopism i innych seryjnych publikacji naukowych wydanych $w$ języku angielskim z dziedziny turystyki. Celem artykułu jest zorientowanie się w ich zakresie, liczbie oraz w zasięgu oddziaływania. Autorzy wyrażają nadzieję, że pomimo trudnego dostępu do wielu $\mathrm{z}$ nich, przegląd ten uzmyslowi znaczenie tych wydawnictw nie tylko dla samej nauki czy kształcenia, ale i dla szybko rozwijającego się przemysłu turystycznego.
\end{abstract}

Prawie połowa pozycji naukowych na świecie wydawanych jest obecnie w języku angielskim, który nazywa się niekiedy współczesną łaciną niemal we wszystkich dziedzinach współpracy międzynarodowej. Dotyczy to zwłaszcza wydawnictw poświęconych badaniom z zakresu turystyki.

Badania nad turystyką zainicjowano na przełomie XIX i XX w. w Austrii, Niemczech, Włoszech i Francji. Pierwsze publikacje naukowe dotyczące turyzmu ukazywały się najpierw w języku niemieckim, później francuskim i włoskim. Dopiero po drugiej wojnie światowej badania nad turystyką podjęto w krajach anglosaskich, najpierw w Wielkiej Brytanii, potem USA i Kanadzie, a ostatnio i w Australii i Nowej Zelandii. W tym samym okresie nastapił także rozwój tego typu badań w Związku Radzieckim, w Jugosławii, Polsce, Czechosłowacji, NRD, Bułgarii i Rumunii.

Obecnie nie ma kraju gospodarczo rozwiniętego, w którym nie funkcjonowałyby, głównie przy uniwersytetach, ośrodki badawcze, prowadzące badania 
nad turystyką. Wydają one różnego rodzaju podręczniki, monografie, niekiedy regularnie ukazujące się czasopisma naukowe, biuletyny, materiały konferencyjne itp. Największy rozwój pod względem jakościowym i ilościowym występuje w grupie wydawnictw anglojęzycznych; dotyczy to zarówno publikacji materiałów badawczych, jak i dydaktycznych. Najbardziej jednak widoczny jest wzrost liczby popularnych turystycznych wydawnictw, takich jak przewodniki, mapy turystyczne i plany miast oraz różnego rodzaju materiały promocyjne (foldery, przewodniki, filmy wideo itp.). Szczególnie jest to zauważalne na półkach księgarskich, gdzie tego typu literatura zajmuje sporo miejsca, jej ekspozycja wzbudza duże zainteresowanie i dynamicznie rośnie jej sprzedaż.

Obecnie ośrodki naukowe nadające ton badaniom nad turystyką znajdują się w krajach anglosaskich oraz w Holandii. Duże tradycje w tej dziedzinie posiadają także placówki naukowe we Francji ${ }^{1}$, Belgii ${ }^{2}$, Niemczech ${ }^{3}$, Szwajcarii ${ }^{4}$, Szwecji ${ }^{5}$ i Austrii ${ }^{6}$. Nowością jest rozwój nauk o turystyce w Hiszpanii, co znalazło odbicie w wydawaniu coraz większej liczby i na wysokim poziomie edytorskim publikacji w języku hiszpańskim. W byłych krajach socjalistycznych po zmianach ustrojowych nastapiło osłabienie działalności badawczej i wydawniczej. Jedynie w Polsce działalność ta została utrzymana w istniejących od lat siedemdziesiątych centrach naukowo-dydaktycznych ${ }^{7}$. Tempo rozwoju badań nad turystyką w Polsce również nie uległo osłabieniu. Zostały one natomiast bardziej ukierunkowane na gospodarczo-marketingowe i ekologiczne aspekty turystyki.

Celem autorów artykułu jest zaprezentowanie ważniejszych, regularnie ukazujących się wydawnictw anglojęzycznych z zakresu turystyki. Z powodu braku dostępu do wszystkich (setek, a może i tysięcy) czasopism, biuletynów, zeszytów naukowych itd., wydawanych nie tylko w krajach anglojęzycznych, ale również $w$ innych państwach $w$ języku angielskim ${ }^{8}$ analiza ograniczona została do najważniejszych - zdaniem autorów - pism, które mają światową renomę wśród wydawnictw naukowych zajmujących się turystyką (rys. 1, tab. I).

Wydawnictwa naukowe $\mathrm{z}$ zakresu turystyki można podzielić generalnie na tradycyjne i wyspecjalizowane. Rozwój informatyki wprowadził wiele innowacji także w zakresie rozpowszechniania informacji naukowej. Efektem tego rozwoju jest pojawienie się stron internetowych różnych czasopism i innych wy-

I W Aix-en-Provence istnieje CHET - Uniwersyteckie Centrum Badań i Dokumentacji Turystycznej.

2 W Brukseli dziala LORETO - grupa wydająca materiały w postaci krótkich informacji o publikacjach naukowych z zakresu szeroko rozumianej turystyki.

3 Znane ośrodki uniwersyteckie wydające czasopisma (,Jahrbuch für Fremdenverkehr”) i podręczniki znajdują się w Monachium, Berlinie, Frankfurcie nad Menem i w Berlinie.

4 Uniwersytety w Zurichu, Bernie, Lozannie i Genewie (czasopismo „Revue de Tourisme”).

5 Uniwersytety w Upsali i w Östersund.

${ }^{6}$ Uniwersytety w Wiedniu i Innsbrucku.

${ }^{7}$ Uniwersytety i uczelnie wyższe w Warszawie, Krakowie, Łodzi, Poznaniu i we Wrocławiu.

${ }^{8}$ Np. w Holandii, Szwajcarii, Szwecji, Chorwacji, Danii i innych krajach. 

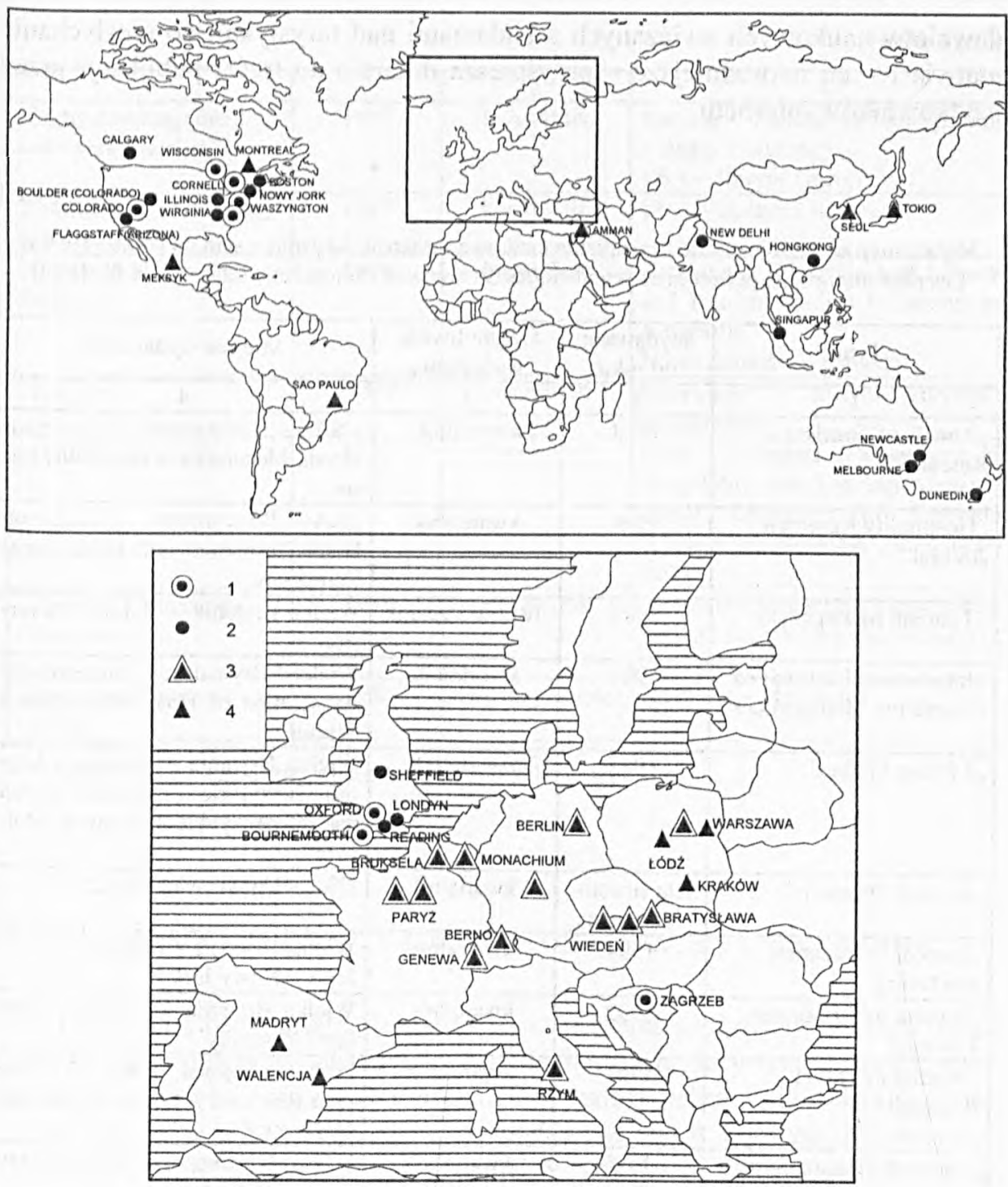

Rys. 1. Miejsca wydawania najważniejszych czasopism naukowych z zakresu turyzmu - stan na koniec $1999 \mathrm{r}$.

1 - czasopisma anglojęzyczne wydawne przed 1980 r., 2 - czasopisma anglojęzyczne wydawane po 1980 r., 3 - czasopisma nie anglojęzyczne wydawane przed 1980 r., 4 -czasopisma nie anglojęzyczne wydawane po $1980 \mathrm{r}$.

Dessin 1. Les lieux ou sont édités les plus importants périodiques du domaine du tourisme (état vers la fin 1999)

1- les périodiques en langue anglaise édités avant 1980,2 - les périodiques en langue anglaise édités après 1980, 3- les périodiques en autres langues que l'anglais édités avant 1980, 4 - les périodiques en autres langues que l'anglais édités après 1980 
dawnictw naukowych związanych z badaniami nad turystyką ${ }^{9}$, co niesłychanie ułatwia i - co najważniejsze - przyśpiesza dotarcie do treści publikacji przez użytkowników internetu.

Tabela I

Najważniejsze anglojęzyczne czasopisma naukowe z zakresu turyzmu - stan na koniec $1999 \mathrm{r}$.

Les plus importants periodiques scientifiques du domaine du tourisme (état vers la fin 1999)

\begin{tabular}{|c|c|c|c|}
\hline Tytul & $\begin{array}{l}\text { Wydawane } \\
\text { od roku }\end{array}$ & $\begin{array}{c}\text { Częstotliwość } \\
\text { wydawania }\end{array}$ & Miejsce wydawania \\
\hline 1 & 2 & 3 & 4 \\
\hline $\begin{array}{l}\text { "Annals of Tourism } \\
\text { Research" }\end{array}$ & 1973 & kwartalnik & $\begin{array}{l}\text { USA - Uniwersytet Wisconsin- } \\
\text {-Stout, Menomona w stanie Wiscon- } \\
\sin \end{array}$ \\
\hline $\begin{array}{l}\text { "Hospitality Research } \\
\text { Journal" }\end{array}$ & 1974 & kwartalnik & $\begin{array}{l}\text { USA - Waszyngton - Council on } \\
\text { Hotel Resteurant and Institutional } \\
\text { Education }\end{array}$ \\
\hline "Tourism Management" & 1979 & dwumiesięcznik & $\begin{array}{l}\text { Wielka Brytania - Oxford Univer- } \\
\text { sity }\end{array}$ \\
\hline $\begin{array}{l}\text { "International Journal of } \\
\text { Hospitality Management" }\end{array}$ & 1981 & kwartalnik & $\begin{array}{l}\text { Wielka Brytania - International } \\
\text { Association of Hotel Management } \\
\text { School }\end{array}$ \\
\hline "Leisure Studies" & 1981 & kwartalnik & $\begin{array}{l}\text { Wielka Brytania - Reading (Ang- } \\
\text { lia), Brytyjskie Zrzeszenia Badań } \\
\text { nad Wypoczynkiem i Czasem Wol- } \\
\text { nym }\end{array}$ \\
\hline "Cornell Quarterly" & $\begin{array}{c}\text { lata siedem- } \\
\text { dziesiąte }\end{array}$ & kwartalnik & USA - Uniwersytet Cornell \\
\hline $\begin{array}{l}\text { „Journal of Vacation } \\
\text { Marketing" }\end{array}$ & 1994 & kwartalnik & $\begin{array}{l}\text { Wielka Brytania - Londyn } \\
\text { USA - Nowy Jork }\end{array}$ \\
\hline $\begin{array}{l}\text { „Journal of Sustainable } \\
\text { Tourism" }\end{array}$ & 1992 & kwartalnik & $\begin{array}{l}\text { Wielka Brytania - Sheffield, Hal- } \\
\text { lam University }\end{array}$ \\
\hline $\begin{array}{l}\text { „Journal of Travel } \\
\text { Research" }\end{array}$ & 1961 & kwartalnik & $\begin{array}{l}\text { USA - Colorado, Travel and Tou- } \\
\text { rism Research Association Boulder } \\
\text { University }\end{array}$ \\
\hline „Tourism Geographies” & 1999 & kwartalnik & $\begin{array}{l}\text { USA - Uniwersytet Pólnocnej Ari- } \\
\text { zony w Flaggstaff }\end{array}$ \\
\hline $\begin{array}{l}\text { „Journal of International } \\
\text { Hospitality, Leisure and } \\
\text { Tourism Managemant" }\end{array}$ & 1997 & kwartalnik & $\begin{array}{l}\text { USA - Department of Hospitality } \\
\text { and Tourism Management Virginia } \\
\text { Polytechnic Institute, Virginia State } \\
\text { University }\end{array}$ \\
\hline „Tourism Economics" & 1976 & kwartalnik & $\begin{array}{l}\text { Wielka Brytania - Międzynarodo- } \\
\text { we Centrum Badań Turystyki na } \\
\text { Uniwersytecie Bournernouth }\end{array}$ \\
\hline
\end{tabular}

${ }^{9} \mathrm{M}$. in. jedno z najnowszych czasopism naukowych z zakresu geografii turyzmu wydawane w USA - „Tourism Geographies” - posiada także stronę w Internecie: http://www.for.nau. edu/geography/tg/. 
Tabela I (cd.)

\begin{tabular}{|c|c|c|c|}
\hline 1 & 2 & 3 & 4 \\
\hline $\begin{array}{l}\text { "Festival Management } \\
\text { and Event Tourism" }\end{array}$ & 1997 & kwartalnik & $\begin{array}{l}\text { Kanada - Faculty of Management } \\
\text { Calgary University } \\
\text { USA - Illinois University }\end{array}$ \\
\hline $\begin{array}{l}\text { "Information Technology } \\
\text { and Tourism" }\end{array}$ & 1997 & kwartalnik & USA - Boston University \\
\hline $\begin{array}{l}\text { "Curent Issues in } \\
\text { Tourism" }\end{array}$ & 1998 & kwartalnik & $\begin{array}{l}\text { Australia - Department of Leisure } \\
\text { and Tourism Studies, University of } \\
\text { Newcastle } \\
\text { Nowa Zelandia - Dunedin }\end{array}$ \\
\hline „Tourism" & $1955^{*}$ & kwartalnik & $\begin{array}{l}\text { Chorwacja - Instytu Turystyki } \\
\text { w Zagrzebiu }\end{array}$ \\
\hline „Tourism Analysis" & 1979 & kwartalnik & $\begin{array}{l}\text { USA - Virginia (Department of } \\
\text { Hospitality and Tourism Manage- } \\
\text { ment), University of Colorado } \\
\text { (College of Business Administra- } \\
\text { tion) }\end{array}$ \\
\hline $\begin{array}{l}\text { "Tourism, Culture and } \\
\text { Communication" }\end{array}$ & 1998 & kwartalnik & $\begin{array}{l}\text { Australia-Melbourne, Victoria Uni- } \\
\text { versity, Technology, Department of } \\
\text { Hospitalty }\end{array}$ \\
\hline $\begin{array}{l}\text { „Journal of Tourism } \\
\text { Studies" }\end{array}$ & 1980 & dwa razy w roku & Australia - Melbourne \\
\hline
\end{tabular}

* Od 1996 r. czasopismo wydawane jest w języku angielskim.

Źr ód ł o: Opracowanie własne.

\section{CZASOPISMA NAUKOWO-BADAWCZE UKAZUJĄCE SIĘ REGULARNIE}

1. „Annals of Tourism Research" - kwartalnik wydawany od 1972 r. Tematyka czasopisma związana jest $\mathrm{z}$ badaniami nad turystyką prowadzonymi głównie w obrębie nauk społecznych. Jego założycielem i długoletnim redaktorem jest Jafar Jafari. Czasopismo to wydawane jest w USA na Uniwersytecie Wisconsin-Stout w Menomonie w stanie Wisconsin. W skład redakcji „Annals of Tourism Research" wchodzą osoby pochodzące z różnych krajów całego świata. Układ pisma jest tradycyjny. Zawiera ono artykuły, notatki, raporty naukowe, recenzje nowych publikacji, a także informacje o różnego rodzaju filmach turystycznych. Oceniając zawartość poszczególnych artykułów, notatek i raportów należy stwierdzić, iż redakcja stara się zachować równowagę pomiędzy teoretyczną a praktyczną stroną badań związanych z turystyką. Istotną cechą publikowanych materiałów w czasopiśmie jest ich interdyscyplinarny charakter. Publikowane są w nim zarówno wyniki badań $\mathrm{z}$ różnych kierunków naukowych, jak i badania kompleksowe. Znaczna część prezentowanych materiałów w cza- 
sopiśmie dotyczy problematyki geograficzno-przestrzennej i planowania przestrzennego.

2. „Hospitality Research Journal” - kwartalnik wydawany od 1974 r. przez Council on Hotel, Restaurant and Institutional Education (CHRIE) ${ }^{10} \mathrm{w}$ Waszyngtonie (USA). Redakcja czasopisma zdominowana jest przez Amerykanów i Kanadyjczyków. W skład 18-osobowego Komitetu Redakcyjnego wchodzą zarówno pracownicy naukowi $\mathrm{z}$ uniwersytetów ${ }^{11} \mathrm{i}$ politechnik, jak i z branży hotelarsko-gastronomicznej. Komitet Redakcyjny regularnie organizuje konferencje, publikując $\mathrm{z}$ nich materiały. Prace zamieszczone na łamach czasopisma posiadają dużą wartość teoretyczno-metodologiczną. Jednocześnie cechą charakterystyczną tych publikacji jest to, że prezentowane $w$ nich wyniki badań $\mathrm{i}$ analiz mają duże znaczenie praktyczne dla rozwijającego się przemysłu turystycznego. Treść większości artykułów dotyczy problematyki ekonomii, zarządzania i marketingu turystycznego, a także psychologii 12 i socjologii turystyki. Sporo uwagi poświęcane jest także sprawom komputeryzacji usług turystycznych oraz różnego rodzaju innowacjom technologicznym w przemyśle turystycznym.

3. „Tourism Management” - dwumiesięcznik wydawany regularnie od roku 1980 w Wielkiej Brytanii. Redaktorem naczelnym po Francisie Brownie jest prof. Steven Wanhill. „Tourism Management” uchodzi za wiodące czasopismo naukowe w dziedzinie turystyki. Prezentowane w nim wyniki badań naukowych maja zastosowanie przede wszystkim w polityce i strategii rozwoju turystyki. Każdy z numerów „Tourism Management” składa się kolejno z następujących części: omówienie zagadnień bieżących, artykuły naukowe, raporty, przegląd literatury specjalistycznej, kalendarz wydarzeń, informacje o autorach. W raportach często przedstawiane są analizy rozwoju turystyki w różnych regionach i krajach. Przykładowo, zeszyt nr 1 z 1995 r. zawierał materiały dotyczące: pożądanych form ekoturystyki, udziału policji w turystyce, Hongkongu i jego przejścia do Chin w 1997 r., turystyki w Czechach i na Słowacji - modeli, problemów i perspektyw, integralnego podejścia do prognozowania popytu w turystyce, przejścia od produktu jakościowego do ekoproduktu na precedensowym przykładzie Fidżi, kreowania kulturowego turystyki zrównoważonej, uporania się linii lotniczych w Azji z globalną konkurencją doniesień turystycznych z Anglii i Kanady - planów i koncepcji rozwojowych turystyki, analiz regionalnych potoków turystycznych w Europie, turystyki i środowiska miast przybrzeżnych, przeglądu literatury.

Czasopismo poświęca dużo uwagi turystyce jako zjawisku przestrzennemu, regionotwórczemu i proekologicznemu.

${ }^{10}$ Zrzeszenie Ksztalcenia w Hotelarstwie i Gastronomii założone w 1946 r.

11 Np. uniwersytety: Cornell, Purdue, Guelph w Ontario (Kanada), Pensylvania, Michigan, Kansas, Central Florida, Nevada i Washington.

12 Zwłaszcza prace dotyczące percepcji. 
4. „International Journal of Hospitality Management” - kwartalnik wydawany od 1981 r. w Wielkiej Brytanii przez International Association of Hotel Management School (IAHMS) ${ }^{13}$, obejmujące swoją działalnością Europę Zachodnią. Redaktorem naczelnym czasopisma jest prof. John O'Connor z Uniwersytetu Brookes w Oxfordzie. Problematyka poruszana w publikacjach ma charakter badawczy, a zarazem praktyczny. Artykuły dotyczą m. in. kierowania kadrami w turystyce, zachowań konsumentów, marketingu turystycznego, planowania turystycznego, kształcenia w turystyce, przetwarzania informacji, międzynarodowego i narodowego ustawodawstwa turystycznego.

5. "Leisure Studies" - kwartalnik ukazujący się od 1981 r., organ Brytyjskiego Zrzeszenia Badań nad Wypoczynkiem i Czasem Wolnym. Redakcja czasopisma mieści się w Reading, a funkcję redaktora naczelnego pełni Mike Stabler. Czasopismo prezentuje przede wszystkim problematykę socjologiczną dotyczącą funkcjonowania wypoczynku, turystyki i sportu w przestrzeni. Zrzeszenie oraz redakcja czasopisma byli inicjatorami powstania międzynarodowej organizacji WLRA (World Leisure and Recreation Association) ${ }^{14}$.

6. "Cornell Quarterly” - kwartalnik wydawany w USA przez Uniwersytet Cornell. Czasopismo ukierunkowane jest wyraźnie na przemysł turystyczny. Prezentowane w nim wyniki badań dotyczą szczególnie spraw technologicznych związanych z infrastrukturą turystyczną (bazą noclegową, gastronomiczną, rozrywkową itp.). Uniwersytet Cornell zajmuje wiodącą pozycję na świecie, jeżeli chodzi o tworzenie programów komputerowych na potrzeby przemysłu turystycznego, nauczania interaktywnego w turystyce, gier dydaktycznych dla potrzeb turystyki, tworzenia studiów przypadków do celów dydaktycznych itd. Działalność ta znajduje szerokie odzwierciedlenie na łamach czasopisma.

7. „Journal of Vacation Marketing” - kwartalnik, którego pierwszy numer ukazał się w 1995 r. Czasopismo wychodzi jednocześnie w Londynie i Nowym Jorku. Artykuły dotyczą głównie marketingu turystycznego. Prezentuje się w nich analizy nowych produktów turystycznych, działalności finansowej biur turystycznych, nowatorskie rozwiązania organizacyjne i technologiczne w turystyce itp.

8. ,Journal of Sustainable Tourism”- jest jednym z nowszych czasopism. Ukazuje się od 1992 r. W skład redakcji wchodzą specjaliści z Wielkiej Brytanii, USA, Kanady, Australii i Irlandii. Redaktorami czasopisma są B. Bramwell z Sheffield Hallam University i B. Lane z Zespołu Turystyki Wiejskiej z Bristolu. Już sama nazwa wskazuje na dominująca problematykę prac publikowanych w czasopiśmie. Dotyczy ona głównie problemu zrównoważonego rozwoju turystyki, analizowanego na różnych przykładach i poziomach - lokalnym, regionalnym i krajowym. Na łamach czasopisma prowadzona jest także dyskusja

13 Międzynarodowe Zrzeszenie Szkół Zarządzania w Hotelarstwie.

14 Światowe Zrzeszenie Czasu Wolnego i Rekreacji. 
teoretyczna nad istotą i perspektywami zrównoważonego rozwoju turystyki. W dyskusji tej zwracana jest szczególna uwaga na szeroki zakres tego pojęcia, uważanego za współczesny paradygmat w naukach o turystyce, a także na wszelkie przejawy i elementy tego rozwoju.

9. „Journal of Travel Research” - interdyscyplinarny kwartalnik wydawany od 1961 r. przez TTRA (Travel and Tourism Research Association) ${ }^{15}$ na Uniwersytecie w Boulder w stanie Kolorado (USA). Na czele Komitetu Redakcyjnego stoi Charles R. Goeldner. Członkowie komitetu redakcyjnego wywodzą się w większości z USA. W dotychczas wydanych zeszytach zaprezentowano przede wszystkim wyniki badań teoretycznych $\mathrm{w}$ postaci rozwiązań modelowych, raportów, studiów przypadków itd. Przykładowo, nr 1 z sierpnia 1999 r. zawierał artykuły dotyczące problemów bezpieczeństwa w turystyce, zwłaszcza wpływu różnego rodzaju zagrożeń (przestępczość, terroryzm, niestabilna sytuacja polityczna w kraju itd.) na rozwój i zarządzanie turystyką. Problematyka tego typu została omówiona na przykładach $\mathrm{m}$. in. Izraela, Północnej Irlandii, Cypru, Nowego Orleanu oraz niektórych krajów azjatyckich.

10. „Tourism Geographies” - jedno z najnowszych czasopism wśród omawianych pozycji. Pierwszy zeszyt tego kwartalnika ukazał się w lutym 1999 r. Czasopismo wydawane jest w USA na Uniwersytecie Północnej Arizony w mieście Flaggstaff. Redaktorem naczelnym jest Alan Lew. Zgodnie z tytułem, problematyka czasopisma skupia się wokół geograficznych aspektów turystyki, jako zjawiska wybitnie przestrzennego. Głównym celem wydawania „Tourism Geographies" jest stworzenie forum wymiany myśli i dyskusji na temat turystyki i wypoczynku z geograficznego punktu widzenia. Zakres merytoryczny pisma jest dość szeroki i różnorodny. Dla podkreślenia starań i wysiłków podejmowanych w celu zaprezentowania szerokiego spektrum różnorodnych podejść badawczych do turystyki, do tytułu dodano celowo określenie ,geographies"- geografie (w liczbie mnogiej). Przestrzenne podejście do badań nad turystyka, wypoczynkiem i czasem wolnym uważane jest przez wydawców za holistyczne i przez to unikalne, gdyż syntetyzuje poglądy z zakresu nauk społecznych i fizycznych, ułatwiając lepsze zrozumienie miejsca, regionu i świata, w którym żyjemy. Czasopismo przeznaczone jest zarówno dla studentów, nauczycieli akademickich, jak i naukowców zajmujących się badaniami geograficznymi z zakresu turystyki. Jest ono także skierowane do ludzi zajmujących się turystyką od strony praktycznej. Artykuły publikowane w każdym numerze „Tourism Geographies" w zależności od treści klasyfikowane są do trzech części zatytułowanych kolejno: Space, Place, Environment (Przestrzeń, Miejsce, Środowisko). Poszczególne tytuły podkreślają geograficzny charakter czasopisma.

11. „Journal of International Hospitality, Leisure and Tourism Management” - kwartalnik wydawany od 1997 r. w USA. Redaktorem tego czasopisma jest

15 Zrzeszenie Badań nad Turystyką i Podróżami. 
Mahmood A. Khan, kierownik Department of Hospitality and Tourism Management ${ }^{16} \mathrm{w}$ Virginia Polytechnic Institute i Virginia State University. Jest to wielonarodowe i wielokulturowe czasopismo prezentujące zaawansowane, przydatne dla praktyków, badania empiryczne dotyczące hotelarstwa, turystyki i wypoczynku. Ostatnio dyskutowane zagadnienia na łamach czasopisma dotyczyły np. zróżnicowania etnicznego $w$ turystyce, infrastruktury transportowej w turystyce, zachowań turystów pochodzących z Tajwanu, percepcji przewodników turystycznych, czynników kształtujących wydatki turystów odwiedzających Kanadę. Zagadnienia w następnym numerze będą dotyczyły takich tematów, jak: możliwości rozwoju międzynarodowej turystyki i hotelarstwa związanych z olimpiadami i ekoturystyką, możliwości rozwoju turystyki w krajach Dalekiego Wschodu i Europy, ponadnarodowe trendy w zakresie rozwoju hotelarstwa i turystyki w XXI w., znaczenie franchisingu w międzynarodowym przemyśle turystycznym oraz globalnego marketingu dla nowo powstających firm turystycznych i hotelarskich. Czasopismo zawiera artykuły badawcze, krótkie notatki, recenzje. Dominuje praktyczny punkt widzenia na poruszane zagadnienia.

12. „Tourism Economics” - kwartalnik wydawany przez Międzynarodowe Centrum Badań Turystyki w Bournemouth University w Wielkiej Brytanii. Redaktorem naczelnym pisma jest prof. S. Wanhill. „Tourism Economics” jest czasopismem dotyczącym turystycznych aspektów biznesu. Główne tematy poruszane na łamach czasopisma związane są z prognozowaniem, rozwojem gospodarczym, polityką społeczną, strukturami rynkowymi i konkurencją na rynkach, źródłami kapitałowymi, ekonomiką pracy (jakość i wydajność), zależnościami pomiędzy prywatnym i publicznym sektorem, modelowaniem matematycznym, strukturą przemysłu turystycznego, ekonomicznymi efektami rozwoju turystyki w regionach, analizami międzynarodowych danych statystycznych WTO dotyczących turystyki na świecie. Ponadto każdy numer zawiera tzw. bazę danych, w której zamieszczone są streszczenia i analizy najnowszych informacji dotyczących turystyki.

13. „Festival Management and Event Tourism”- kwartalnik o zasięgu międzynarodowym, którego redaktorami są prof. Donald Getz z Uniwersytetu w Calgary (Kanada) i prof. Bruce Wicks z Uniwersytetu Illinois (USA). Czasopismo zostało powołane w celu zaspokojenia potrzeb rozwijającej się branży przemysłu turystycznego związanej z organizacją kongresów, festiwali i innego typu podobnych wydarzeń na świecie. Branża te w sposób znaczący wpływa obecnie na rozwój światowego przemysłu turystycznego. W skali międzynarodowej rozwinęła się ona na ogromną skalę.

14. „Information Technology and Tourism” - jest to pierwsze naukowe czasopismo, którego treść dotyczy wzajemnych relacji pomiędzy współczesną technologią informacyjną a turystyką. Globalna sieć połączeń informacyjnych i ko-

16 Katedra Zarządzania Hotelarstwem i Turystyka. 
munikacyjnych ma ogromny wpływ na rozwój turystyki. Systemy rezerwacyjne, multimedialne, rynek elektroniki, znacząca pozycja usług turystycznych dostępnych za pośrednictwem internetu, jak i zastosowanie badań naukowych w turystyce są godnymi uwagi rezultatami tego rozwoju. Czasopismo ma charakter wielodyscyplinarny. Zamierzeniem redakcji "Informtion Technology and Tourism” jest pokazanie relacji pomiędzy badaniami z zakresu turystyki a wspólczesnymi technologiami informacyjnymi. W artykułach prezentowane są zarówno wyniki badań empirycznych, jak i bardziej praktycznych, pokazujących współczesną turystykę z punktu widzenia technologii informacyjnych i na odwrót - technologie informacyjne z punktu widzenia współczesnej turystyki. Czasopismo wydawane jest w USA.

15. „Current Issues in Tourism” - kwartalnik wydawany przez Department of Leisure and Tourism Studies na Uniwersytecie w Newcastle (Australia). Redaktorem czsopisma jest dr John Jenkins. Celem wydawców „Current Issues in Tourism” jest szczegółowa prezentacja badań dotyczących prowadzenia polityki turystycznej oraz rozwoju turystyki w krajach rozwiniętych i rozwijających się. Ważnym aspektem publikowanych w czasopiśmie artykułów jest łączenie wiedzy teoretycznej i praktycznej dotyczącej turystyki. Zdaniem redakcji problem prowadzenia polityki turystycznej jest często zaniedbywany $w$ badaniach związanych z turystyką. Badania te powinny obejmować następujące zagadnienia: rola państwa w tworzeniu polityki turystycznej; krytyka polityki rządowej; ocena skutków polityki turystycznej; podział zadań w zakresie polityki turystycznej; wpływ grup nacisku na sektor publiczny; rola publicznych i prywatnych przedsiębiorstw w rozwoju turystyki i marketingu; ekonomia polityczna turystyki; historia organizacji turystycznych i administarcji samorządowej (od narodowych po lokalne grupy nacisku społecznego); porównanie polityki turystycznej prowadzonej w różnych krajach; liderzy w tworzeniu przepisów i narzędzi polityki turystycznej; analizy objaśniające sposoby prowadzenia polityki turystycznej; stosunek polityki turystycznej do ludności miejscowej oraz kierunki jej rozwoju.

16. „Tourism” - międzynarodowy kwartalnik akademicki i zawodowy, w którym publikowane są artykuły dotyczące różnorodnych aspektów turystyki, związany zarówno $\mathrm{z}$ badaczami, jak i praktykami z dziedziny turyzmu. Redakcja czasopisma kładzie szczegółny nacisk na szerokie powiązania z przemysłem turystycznym; wielodyscyplinarne podejście dotyczy takich dziedzin jak ekonomia, marketing, geografia, socjologia, antropologia, hotelarstwo, historia itp. Publikacje prezentowane w analizowanym czasopiśmie mają najczęściej formę artykułów, notatek naukowych, raportów, sprawozdań z konferencji, wiadomości o nowościach w zakresie programów edukacyjnych, recenzji itp. „Tourism” wydawany jest w Chorwacji już od 45 lat. Od 1996 r. czasopismo ukazuje się w języku chorwackim i angielskim, a od 2000 r. będzie wydawane tylko w języ$\mathrm{ku}$ angielskim. 
17. „Tourism Analysis” - celem czasopisma jest promocja wspólnego forum dla praktyków i teoretyków z zakresu szeroko rozumianej turystyki (LRTH Leisure, Recreation, Tourism, and Hospitality). Artykuły, notatki naukowe a także różnego rodzaju rozwiązania komputerowe, programy prezentowane $\mathrm{w}$ tym wielodyscyplinarnym czasopismie mają wartość praktyczną zarówno dla profesjonalistów, jak i wykładowców, naukowców i studentów studiujących w zakresie turystyki na całym świecie. Artykuły dotyczą m. in. modeli zachowań, technik podejmowania decyzji, modeli estymacji, systemów monitoringu, oceny atrakcyjności turystycznej, nowych narzędzi analiz, metod badań, rozwoju baz danych, zastosowań technik kopmuterowych. W skład komitetu redakcyjnego wchodza profesorowie Muzaffer Uysal z Department of Hopsitality and Tourism Management, Virginia Technical University, i Richard R. Perdue z College of Business and Admninistration, Univeristy of Colorado (USA). Redaktorem na Europę jest prof. Josef Mazanec z Instytutu Turystyki i Rekreacji Uniwersytetu w Wiedniu.

18. „Tourism, Culture \& Communication” - czasopismo o zasięgu międzynarodowym, wydawane w Victoria University of Technology, Department of Hospitality w Melbourne (Australia). Wydawnictwo to wprowadza wielodyscyplinarne podejście w badaniach związanych z niektórymi aspektami inaczej niż tradycyjnie pojmowanej kultury narodowej czy miejscowej, np. zachowania ludzkie wobec problemu zarządzania turystyką osób niepełnosprawnych, turystyka trzeciego wieku (ludzi starszych). Czasopismo prezentuje wysoki poziom merytoryczny. Na łamach czasopisma ukazują się głównie artykuły, publikacje skierowane na teorię i praktykę, recenzje i studia przypadków.

19. „Journal of Tourism Studies” - publikuje artykuły z zakresu turystyki, napisane zarówno przez naukowców jak i praktyków, różnych dziedzin nauk ekonomicznych, matematyczno-przyrodniczych, socjologicznych i humanistycznych. Czasopismo ma zasięg międzynarodowy. Publikacje w nim prezentowane opierają się na oryginalnym materiale badawczym oraz przeprowadzonych dyskusjach analitycznych odnoszących się do praktycznej strony turystyki. Intencją redakcji jest dotarcie do jak największej grupy osób zatrudnionych w przemyśle turystycznym, dla których, zdaniem wydawcy, treści prezentowane w tym czasopiśmie są najbardziej interesujące i odpowiednie. Czasopismo jest także przydatne dla osób zajmujących się planowaniem oraz kształceniem w zakresie turystyki. „Journal of Tourism Studies” ukazuje się dwa razy w roku, w maju i grudniu.

Wszelkie istotne informacje na temat przedstawionych czasopism, należących do wiodących na świecie wydawnictw naukowych $w$ dziedzinie szeroko rozumianej turystyki, można znaleźć także w różnego rodzaju czasopismach bibliograficznych, takich jak „Tourism and Travel Index”, „Leisure, Recreation and Tourism Abstracts", "Social Sciences Citation Index". Szczególnie ważny 
w tej grupie jest kwartalnik „Leisure, Recreation and Tourism Abstracts”, wydawany w Wielkiej Brytanii jako osobne czasopismo. Inne podobne wydawnictwa to „Tourism Economies”, „Festival Management and Event Tourism”, o których autorzy nie mieli wystarczających informacji.

\section{ATLASY TURYSTYCZNE, MONOGRAFIE, RAPORTY I BIULETYNY NAUKOWO-INFORMACYJNE}

W tej części zostaną zaprezentowane publikacje, które mają charakter naukowy i związane sa z badaniami stosowanymi.

1. „World Travel Atlas” - specjalnie przeznaczony dla branży turystycznej, stanowi unikalne kompendium wiedzy dotyczącej turystyki przedstawionej na mapach tematycznych i w zestawieniach statystycznych (tabele i wykresy). Do roku 1999 ukazało się sześć tomów. Ostatnie wydanie zawiera m. in. mapy stref klimatycznych, czasowych, zagrożeń zdrowia, regulacji transportowych, głównych portów lotniczych, morskich, linii kolejowych, połączeń promowych, walorów kulturowych i wypoczynkowych, rozmieszczenie parków narodowych, oraz ważniejszych regionów turystycznych świata. Ponadto w atlasie można znaleźć tzw. „ślepe mapy”, umożliwiające rozpoznawanie np. stolic, ważniejszych miast, regionów, granic. W przygotowaniu jest kolejny, siódmy, numer, w którym zaprezentowane zostaną $\mathrm{m}$. in. mapy rozmieszczenia muzeów i galerii sztuk, walorów turystycznych wschodnich Karaibów itd. „World Travel Atlas” przydatny jest zarówno osobom tzw. z branży, zajmujących się turystyka, jak i zajętych kształceniem na potrzeby turystyki. Przede wszystkim można tam odnaleźć wiele istotnych, przydatnych i aktualnych informacji turystycznych, których nie ma w żadnym innym wydawnictwie o charakterze informacyjnym. Atlas jest rekomendowany przez stowarzyszenia agentów turystycznych, takich jak ASTA (American Society of Travel Agents), WATA (World Association of Travel Agents), PATA (Pacific Asia Travel Association).

2. „Leisure, Recreation and Tourism Abstracts” - kwartalnik prezentujący streszczenia różnojęzycznych prac naukowych, monografii turystycznych, podręczników ze wszystkich znanych kierunków wiedzy i praktyki turystycznej. Publikacja wydawana jest przez CAB (International Information Services). Ukazuje się jednocześnie w USA i w Anglii. Redaktorem naczelnym jest Bernadette Quinn. Komitet redakcyjny tworzy duża grupa osób składająca się z ekonomistów, geografów, leśników, przedstawicieli WTO (World Travel Organisation) i innych. Każdy z numerów składa się z rozdziałów: 1) ogólnego, dotyczącego turystyki, rekreacji i wypoczynku; 2) o walorach turystycznych i środowisku; 3) o turystyce i podróżach; 4) o rekreacji i sporcie; 5) o sztuce i rozrywce; 6) o rekreacji w domu i otoczeniu. W każdym numerze znajduje się także baza danych. 
3. „International Tourism Reports” - kwartalnik wydawany w Wielkiej Brytanii, prezentujący statystyczne analizy rynków turystycznych różnych krajów. Początkowo, w latach siedemdziesiątych, „International Tourism Reports” ukazywał się jako dodatek do znanej gazety "The Economist”. Od lat osiemdziesiątych pismo ukazuje się osobno, jako raporty poświęcone poszczególnym krajom lub zagadnieniom.

4. „Travel and Tourism Analyst” - kwartalnik o podobnej genezie jak poprzednio omawiane pismo, wydawany z myślą o ekspertach i decydentach w zakresie szeroko rozumianej turystyki. Ukazuje się w Wielkiej Brytanii. Redaktorzy pisma kładą nacisk na analizy problemowe współczesnego przemysłu turystycznego. Na przykład nr 3 z 1998 r. dotyczył przyszłości globalnych systemów dystrybucji usług turystycznych, turystyki wyjazdowej Chin, struktury własności w europejskim przemyśle turystycznym, potoków kapitałowych w azjatyckim hotelarstwie, zainteresowania turystycznego dziedzictwem historycznym małych miast. Prezentowane w „Travel and Tourism Analyst” analizy są bardzo rzetelne i krytyczne. W dużej mierze korzystają z nich najwięksi na świecie aktorzy współczesnego przemysłu turystycznego, kreując na ich podstawie swoja politykę. Jest to, podobnie jak „International Tourism Reports”, publikacja wydawana w niewielkim nakładzie, dość droga i rozprowadzana wyłącznie na zamówienie.

5. „World Travel” - biuletyn wydawany w Madrycie przez WTO (World Tourism Organisation), ukazuje się w kilku językach. Jest to dwumiesięcznik zawierający oficjalne stanowiska i komunikaty WTO, a także różnego rodzaju materiały i krótkie artykuły naukowe.

6. „Atlas News” - biuletyn znanego europejskiego zrzeszenia szkół turystycznych ATLAS ${ }^{17}$, które ostatnio rozszerzyło swoją działalność także na kraje Azji i Afryki. Koordynatorem zrzeszenia i jednocześnie redaktorem pisma jest Greg Richards. W biuletynie publikowane są przede wszystkim bieżące informacje dotyczące działalności ATLAS-u, a także krótkie artykuły badawcze i dydaktyczne prezentujące współczesne trendy w zakresie kształcenia na potrzeby turystyki. Do chwili pisania tej pracy ukazało się 20 numerów „Atlas News”. Innym wydawnictwem ATLAS-u są praktyczne informatory (ATLAS Handbook) o nowych członkach zrzeszenia, szkołach turystycznych, programach nauczania w dziedzinie turystyki, prowadzonych kursach. Można się z nich dowiedzieć

17 The European Association for Education in Tourism and Leisure (ATLAS) powstało w $1991 \mathrm{r}$. Celem działalności tej organizacji jest promowanie edukacji w zakresie turystyki i rekreacji w Europie, rozwój wymiany kadry naukowej i studentów pomiędzy instytucjami należącymi do ATLAS-u, rozwijanie powiązań pomiędzy przemysłem turystycznym a ośrodkami ksztalcącymi na potrzeby szeroko rozumianej turystyki oraz wspieranie rozwoju międzynarodowych programów badawczych i edukacyjnych. Obecnie (1999 r.) do ATLAS-u należy 213 różnego rodzaju instytucji, głównie uniwersytetów, z 42 krajów. Komitet koordynacyjny ATLAS-u mieści się w Uniwersytecie w Tilburgu (Holandia), Department of Leisure Studies. 
adresów różnych instytucji wymienianych w informatorze, kosztach studiowania itp. Biuletyn rozpowszechniany jest głównie wśród członków stowarzyszenia ATLAS. Materiały publikowane zarówno w „Atlas News", jak i ATLAS Handbook są dostępne także na stronach internetowych zrzeszenia ATLAS ${ }^{18}$.

7. „Tourist Info" - publikacja wydawana nieregularnie od 1988 r. przez Kierownictwo Grupy Roboczej Turystyki Zrównoważonej działająca z ramienia Międzynarodowej Unii Geograficznej. Do 1996 r. redaktorem czasopisma był prof. F. Helleiner z Kanady. Obecnie funkcję tę sprawuje Michael Hall z Nowej Zelandii. Biuletyn ten jest rozprowadzany głównie wśród członków grupy.

8. „Highlihgts" - należy do grupy pism wydawanych przez studentów i absolwentów. W tym wypadku jest to raczej gazeta (miesięcznik). Jej wydawaniem zajmują się studenci i absolwenci wyższej szkoły hotelarskiej w Hadze. „Highlihgts” ukazuje się od 1974 r.

Dokonany przegląd czasopism i innego typu publikacji związanych z turystyką miał na celu głównie zorientowanie się w ich zakresie, liczbie oraz zasięgu oddziaływania. Autorzy wyrażają nadzieję, że pomimo trudnego czasami dostępu do wielu $\mathrm{z}$ nich, przegląd ten uzmysłowi znaczenie tych wydawnictw nie tylko dla samej nauki czy kształcenia, ale i dla szybko rozwijającego się przemysłu turystycznego.

Należy także podkreślić, że coraz bardziej popularne, a przez to i łatwiej dostępne, staje się przekazywanie informacji o czasopismach $\mathrm{i}$ innych wydawnictwach w Internecie. Choć w przemyśle turystycznym Internet jest obecnie wykorzystywany na dużą skalę (np. globalne systemy rezerwacji i informacji oraz dystrybucji innych materiałów i usług turystycznych), to jednak niewiele jest jeszcze moźliwości dotarcia tą drogą do informacji zawartych w czasopismach. Dotyczy to głównie materiałów o charakterze naukowym, badawczym, podczas gdy informacje typowo turystyczne dotyczące produktu turystycznego są już powszechnie dostępne na stronach Internetu ${ }^{19}$.

Prof. dr hab. Marin Baczwarow

Wpłynęto:

Dr Robert Wiluś

29 listopada 1999 r.

Katedra Geografii Miast i Turyzmu

Uniwersytet Lódzki

ul. Kopcińskiego 31

90-142 Łódź

${ }^{18}$ http://www.atlas-euro.org.

19 Przygotowując niniejszą publikację autorzy korzystali z materiałów promocyjnych, czasopism, atlasów i serii wydawniczych oraz ze stron internetowych www omawianych lub wspomnianych w artykule tytułów. 
A présent, il n'y a pas de pays développés économiquement, dans lesquels il n'y ait pas de centres de recherches, le plus souvent près des universités, s'occupant de tourisme. Ils éditent des manuels divers des monographies, parfois des périodiques scientifiques paraissant régulièrement, des bulletins, des matériaux de conférences, etc. Le plus grand développement, ainsi du point de vue qualitatif que celui quantinatif, se fait voir dans le groupe des éditions en langue anglaise. Cela se rapporte aussi bien aux matériaux de recherches qu'à ceux didactiques. Cependant la plus visible est la hausse des éditions touristiques en vogue, tels les guides, les cartes touristiques, les plans de villes et les matériaux de promotion différents (pliants, guides, films video, etc.). Cela est à remarquer sur les rayons de librairies, où une telle littérature occupe beaucoup de place et son exposition attire l'attention de clients et la vente croit dynamiquement.

L'article a pour but la présentation des éditions touristiques paraissant régulièrement en langue anglaise. Vu l'impossibilité d'accéder à tous les périodiques, bulletins et cahiers scientifiques (dont le nombre est de quelques centaines ou milliers) édités en langue anglaise non seulement dans les pays anglophones, l'analyse est bornée aux périodiques, selon les auteurs, les plus importants, ayant la renommée parmi les éditions scientifiques s'occupant de tourisme.

Ces éditions sont traditionnelles ou spécialisées. Le développement des moyens d'informer a entraîné plusieurs innovations aussi dans le domaine de la vulgarisation de information touristique. C'est à ce dèveloppement que les pages de l'internet www de différents périodiques et autres éditions scientifiques liés aux recherches sur le tourisme doivent leur puration. Elles facilitent et accélèrent l'accès aux publications pour les usagers d'internet.

La revue des périodiques et autres matériaux liés au tourisme, qu'on a faite, a pour but l'orientation dans leur sphère et l'étendue de leur influence. Quoique certains périodiques soient difficilement accessibles, les auteurs espèrent que la revue démontrera l'importance de ces éditions non seulement pour la science elle-même ou l'enseignement, mais aussi pour l'industrie touristique qui se développe rapidement.

Il faut souligner que le transfert des informations sur les périodiques et autres magazines à l'internet devient de plus en plus connu et par cela plus accessible. Bien que l'internet soit exploité dans l'industrie touristique sur une grande échelle (par ex. les systèmes globaux ainsi de réservation et d'information que de distribution d'autres matériaux et services touristiques) les possibilités de parvenir par cette voie à la teneur des articles compris dans les périodiques sont toujours limitées. Cela se rapporte avant tout aux matériaux au caractère scientifique et de recherche, tandis que les informations typiquement touristiques concernant le produit touristique sont largement accessibles sur les pages www.

Traduit par Lucjan Kowalski

\section{SUMMARY}

Nowadays there is no economically developed country without university research centres which conduct studies of tourism. They issue a variety of reference books, monographs, sometimes also science periodicals, newsletters, conference materials, etc.

The most dynamic development, both as far as the quantity and the quality are concerned, occurs among English publications. It concerns both the research and the teaching materials. 
The most evident, however, is the rise in the popular tourist publications, such as guides, tourist maps and city plans, as well as various promotion materials (brochures, guides, video films, etc.). It is particularly observable in book shops, where this type of literature occupies a considerable amount of space, its display attracts the customers' attention and the sales increase.

The authors' aim is to present the more significant English publications on tourism, issued regularly. Because of the lack of access to all (hundreds, perhaps thousands) the magazines, brochures, scientific publications, etc., issued in English not only in English-speaking countries, the analysis was limited to the most important, in the authors' view, magazines, which are well known among the scientific publications dealing with tourism.

The scientific publications dealing with tourism can be generally divided into traditional and specialized. The development of computer science brought about numerous innovations as far as popularizing scientific information is concerned. As a result there appeared internet pages www. of different magazines and other scientific publications dealing with research into tourism, which considerably facilitates and accelerates reaching the contents of the publications by the internet users.

The review of magazines and other types of publications dealing with tourism mainly aims at establishing their thematic scope, amount and range of influence. The authors hope that, despite difficult access to many of them, the review will show the importance of these publications, not only to science or education themselves, but also to the briskly developing tourist industry.

It should also be stressed that passing information about magazines and other publications via internet is becoming more and more popular, making it easily available. Although in the tourist industry the internet is presently used on a large scale (e.g. global reservation and information systems, systems of distributing other materials and tourist services), the possibilities to reach the contents of magazine articles are still scarce. It mainly provides scientific, research materials, while typically tourist information about the tourist product is commonly accessible via the www. pages. 